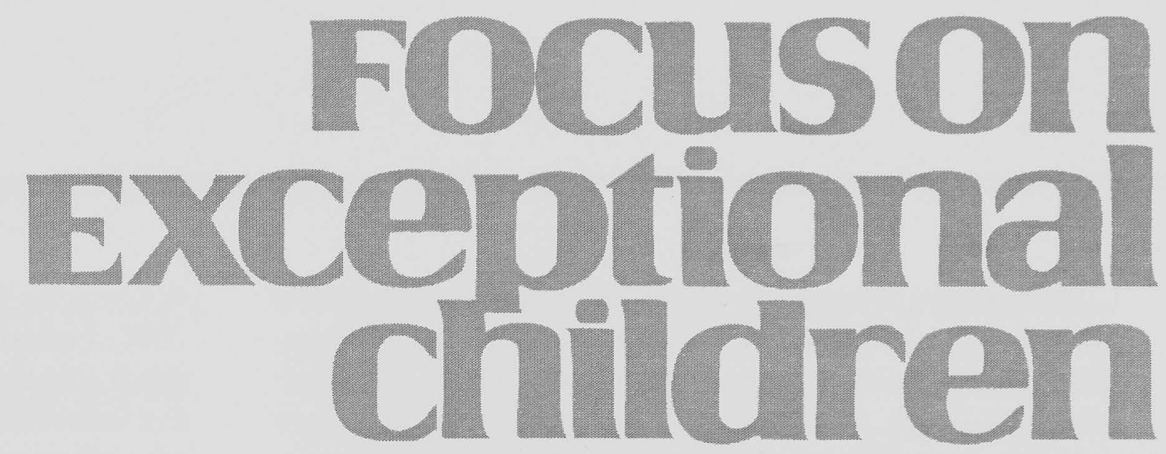

\title{
Robust Reading Instruction in the Early Grades: Conceptual and Practical Issues in the Integration and Evaluation of Tier 1 and Tier 2 Instructional Supports
}

\author{
Scott K. Baker, Hank Fien, and Doris Luft Baker
}

Schools implement Response to Intervention (RtI) for two major purposes. The first is to provide a coordinated system of high-quality instruction and intervention for all students in the school (Burns \& Vanderheyden, 2006; Haager, Klinger, \& Vaughn, 2007; National Association of State Directors of Special Education, 2006). This system can be envisioned as a framework of effective instruction to prevent academic problems from occurring and effective interventions to address problems that do occur in a timely and appropriate manner. The system is integrated and coordinated to support all students to reach primary learning objectives (Fuchs, Fuchs, \& Zumeta, 2008; Greenwood, Kratochwill, \& Clements, 2008). The second purpose of RtI is to diagnose specific learning disabilities (SLD) in students who do not respond adequately to instruction and intervention (O'Conner, 2007; Reynolds \& Shaywitz, 2009; Torgesen, 1997, 2004). Strong empirical evidence supports the prevention and intervention purpose of RtI (Baker et al., 2008; Gersten et al., 2009; Greenwood, Kratochwill, \& Clements, 2008; Vaughn \& Fuchs, 2006), but evidence for using RtI for SLD determination is lacking (Fuchs, Mock, Morgan, \& Young, 2003; Reynolds \& Shaywitz, 2009).

\section{RTI PREVENTION AND INTERVENTION}

We contend that schools cannot validly implement RtI for SLD determination unless they have first established a robust system of prevention and intervention. Once that system is firmly established in the school and evidence clearly demonstrates that the system is working effectively for students, then RtI for SLD determination may be appropriate. This article addresses the purpose of RtI as a comprehensive service delivery system designed to prevent academic problems, to detect problems that do occur early, and to intervene quickly to reduce the negative consequences of problems efficiently and effectively (Greenwood, Kratochwill, \& Clements, 2008; Greenwood, Horner, \& Kratochwill, 2008). To provide context for understanding both purposes of RtI, a secondary purpose is to link multiple tiers of support to RtI for SLD determination.

Dr. Scott Baker is the Associate Director of the Center on Teaching and Learning at the University of Oregon and the Director of Pacific Institutes for Research. Dr. Fien and Dr. Doris Luft Baker are research associates at the Center on Teaching and Learning at the University of Oregon. 
The phrase response to intervention does not adequately describe the multifaceted, comprehensive nature of a prevention and intervention service delivery model. Terminology that clearly distinguishes RtI for prevention and intervention from RtI for SLD identification would increase precision for researchers and reduce confusion in schools that describe themselves as implementing RtI. Without a clearer distinction, the underlying spirit of RtI as an integrated and comprehensive system of instruction and intervention that supports all students in a school is compromised. In theory, the comprehensive implementation of an RtI system would incorporate all elements of high-quality prevention and intervention and include the tools and technology necessary to use RtI for SLD determination. This comprehensive system would include a host of reliable and valid assessment instruments for different purposes (i.e., screening, progress monitoring, diagnosis, summative achievement, classroom based formative measures, curriculum embedded assessments) and procedures for collecting, summarizing, analyzing, and using data to inform instruction (e.g., data-based decision-making teams, effective leaders adept with measurement) (Greenwood, Horner,

\section{Focuson
Exceptional
children}

ISSN 0015-511X

FOCUS ON EXCEPTIONAL CHILDREN (USPS 203-360) is published monthly except June, July, and August as a service to teachers, special educators, curriculum specialists, administrators, and those concerned with the special education of exceptional children. This publication is annotated and indexed by the ERIC Clearinghouse on Handicapped and Gifted Children for publication in the monthly Current Index to Journals in Education (CIJE) and the quarterly index, Exceptional Children Education Resources (ECER). The full text of Focus on Exceptional Children is also available in the electronic versions of the Education Index. It is also available in microfilm from Serials Acquisitions, National Archive Publishing Company, P.O. Box 998, Ann Arbor, MI 48106-0998. Subscription rates: individual, $\$ 48$ per year; institutions, \$66 per year. Copyright (C) 2010, Love Publishing Company. All rights reserved. Reproduction in whole or part without written permission is prohibited. Printed in the United States of America. Periodical postage is paid at Denver, Colorado. POSTMASTER: Send address changes to:

Love Publishing Company

Executive and Editorial Office

P.O. Box 22353

Denver, Colorado 80222

Telephone (303) 221-7333

\section{CONSULTING EDITORS}

Steve Graham

Vanderbilt University
Ron Nelson

University of Nebraska-Lincoln

Eva Horn

University of Kansas

Carrie E. Watterson

Senior Editor
Stanley F. Love

Publisher
\& Kratochwill,, 2008; Greenwood, Kratochwill, \& Clements, 2008; Haager et al., 2007). Raudenbush (2008) described this feedback loop as an instructional regime, where effective instruction is viewed as a continuous, dynamic interplay of assessment and instruction. The culmination of this assessment-instruction feedback system could be the use of RtI for SLD determination.

In RtI prevention and intervention, different levels of instruction and intervention are provided to students based on need. In early reading, instructional need is conceptualized in two ways: (a) the student's current level of achievement is described in relation to a performance standard and (b) the student's growth over time is described in relation to a standard for adequate growth (Fuchs, Fuchs, McMaster, \& Al Otaiba, 2005). The concept of academic growth is hallowed ground in RtI, and the interpretation of student growth contains significant programmatic implications. Adequate growth generally means the student's instructional needs are being met and efforts are undertaken to maintain the student's instructional program. In this case, the student has responded positively to instruction. When growth over time is less than adequate, an essential first step is to rule out poor instruction or implementation as a probable cause of insufficient progress (Clements \& Kratochwill, 2009; Fuchs et al., 2003). Our experience is that, by and large, schools currently either ignore this step or treat it perfunctorily. When instruction is of high quality and the student has not made adequate progress, the interpretation is that the student has not responded positively to instruction. In this case, the basic idea is that instruction should be changed in some manner, usually by increasing instructional intensity, so that the probability of the student responding positively in the future is increased.

\section{Multiple Tiers of Instruction}

In RtI prevention and intervention, instructional intensity is manipulated through levels of intervention, referred to broadly as instructional tiers. The most common model is the three-tier model (Chard et al., 2008; Haager et al., 2007; Walker \& Shinn, 2002). Recently, the Institute of Education Sciences (IES) released a practice guide on RtI and multitier instruction and intervention in the primary grades (Gersten et al., 2008). Five recommendations are targeted to districts and schools seeking to effectively implement an RtI system:

1. Screen all students for potential reading problems at the beginning of the year and again in the middle of the year.

2. Provide time for differentiated reading instruction for all students based on assessments of students' current reading level.

3. Provide intensive, systematic instruction on up to three foundational reading skills in small groups to 
students who score below the benchmark on universal screening.

4. Monitor the progress of Tier 2 students at least once a month.

5. Provide intensive instruction on a daily basis that promotes the development of the various components of reading proficiency to students who show minimal progress after reasonable time in Tier 2 small group instruction (Tier 3).

As in all 12 IES practice guides, the authors of the practice guide, who are considered experts in the area, rated the level of scientific evidence as low, moderate, or high for each recommendation. In the RtI practice guide, Recommendation 2 addressed Tier 1 or core instruction in a multitier approach and Recommendation 3 addressed Tier 2 . The evidence base for the Tier 1 recommendation was considered low by the panel (one correlation study was offered as scientific evidence) and the evidence base of the Tier 2 recommendation was considered strong (11 intervention studies were offered as scientific evidence). The fifth recommendation addressed instruction in Tier 3, and the evidence for this was determined to be low. The first and fourth recommendations addressed screening and progress monitoring assessments (the evidence was moderate and low for each, respectively). The focus of our article is on Tier 1 (Recommendation 2) and Tier 2 (Recommendation 3 ) in early reading instruction.

Clearly, much more is known about effective early reading instruction in Tier 2 than in Tiers 1 or 3 (Gersten et al., 2008). The findings regarding Tier 2 show a high degree of consistency and strong consensus on the implications for districts and schools working to translate research to practice (Gersten et al., 2008). The major conclusion of this research is that approximately 30 minutes of small group instruction each day (3-5 days per week) is highly effective for students who are struggling with learning to read. The way instruction is provided is carefully described in these studies, which demonstrate consistency in how instruction should be delivered by the teacher.

Virtually all recommendations of Tier 2 instruction focus on the fundamental and foundational importance of explicit instruction (Gersten et al., 2008). A number of components define explicit instruction across Tier 2 interventions. Essential components are (a) teachers model the skills and knowledge they expect students to use and apply (Mathes et al., 2005), (b) teachers provide multiple practice opportunities for students during the lesson (Gunn, Smolkowski, Biglan, Black, \& Blair, 2005; Vadasy, Sanders, \& Peyton, 2005), (c) teachers correct and or address student errors and misunderstandings immediately and systematically (Gunn et al., 2005), and (d) teachers pace lessons in a brisk manner so that student engagement is high and so that multiple areas of reading development (e.g., phonemic awareness, vocabulary, word reading) can be addressed in the 30-minute lesson.
The purpose of these research studies is to test the effectiveness of Tier 2 instruction. In most studies, random assignment is used and Tier 1 instruction is not addressed. For example, most of the studies do not state what the Tier 1 instructional program is. The Tier 2 programs use separate materials, and the integration of Tiers 1 and 2 is not described. Conceptually, however, Tier 2 early reading instruction is supposed to directly supplement (not replace) Tier 1 instruction, and, in most conceptualizations of the three-tier model, Tier 2 is provided in addition to Tier 1 instruction (Vaughn, Wanzek, Woodruff, \& Linan-Thompson, 2007, p. 19).

Over the past 7 years, Reading First (RF) in Oregon has been implemented through the Schoolwide Reading Model (Baker, et al., 2008; Kame'enui, Simmons, \& Coyne, 2000; Simmons et al., 2002), a model tightly aligned with the goals and structure of RtI prevention and intervention. In Oregon RF, we have learned important lessons about the integration and alignment of Tier 1 and Tier 2 instruction. Regarding Tier 1, these experiences can be crystallized into three essential conclusions:

1. Core reading programs in Tier 1 can be implemented effectively in schools (Baker, Gersten, Haager, \& Dingle, 2006).

2. The effective use of a common core program across grades increases instructional integration and cohesion.

3 . If reading outcomes are to be improved substantially - and they must be if all students are going to reach high levels of early reading proficiency (e.g., reading at grade level by third grade) - then additional large-scale improvements in the effective implementation of Tier 1 instruction must occur.

Toward that end, our experience is that substantial improvements can be made to structural and delivery elements (Biancarosa \& Snow, 2006; Gersten, Chard, \& Baker, 2000) within Tier 1 programs to make instruction more systematic and explicit, and these improvements will result in substantially better learning outcomes for students.

Regarding Tier 2, our experience is that better integration of Tier 1 and Tier 2 instruction is also essential to improve reading outcomes for students who struggle with learning to read. Schools can effectively implement Tier 2 instruction in multiple ways. One approach involves implementing separate programs and materials that supplement Tier 1 instruction (Gersten et al., 2008). A second approach involves using Tier 1 materials to intensify instruction through small group formats and other procedures.

\section{Purpose of Article}

Although either approach is viable, the purpose of this article is to present a model focusing on the second 
approach: early reading instruction that relies on the core reading program as the foundation for both Tier 1 and Tier 2 instruction. The basic idea in this model is that students who receive all of the components of Tier 2 instruction also receive all of the components of Tier 1 . In this model, the same basic program materials are used for core instruction (Tier 1) and supplemental instruction (Tier 2). We propose that this tight integration of Tiers 1 and 2 may be particularly effective in early reading, illustrating one way schools may be able to provide an effective system of reading instruction in the primary grades.

The tight integration of Tiers 1 and 2 may be uniquely suited for reading instruction in the early grades. In the higher grades, as learning content becomes more complex, the discrepancy between the instructional objectives in Tiers 1 and 2 may expand. For example, a fifth grade student struggling with decoding may work on this objective in Tier 2 small-group instruction. This daily decoding intervention may be disconnected from the Tier 1 core reading time. That is, the Tier 1 program may not have any decoding instruction, or the instruction might be on word types that are well beyond the instructional level of the struggling student.

In the next section, we describe ways to achieve better integration of instructional supports across Tiers 1 and 2 . Then, we provide a framework for evaluating the effectiveness of different tiers of instructional support using two major data sources: (a) student reading data and (b) instruction and intervention implementation data.

\section{INTEGRATED INSTRUCTION USING TIERS 1 AND 2}

In the early reading model we present, Tier 1 instruction is provided through the use of a core reading program (Simmons \& Kame'enui, 2000). Tier 2 instruction is provided either through the more intense instructional use of the core Tier 1 program (our focus in this paper) or through separate supplemental materials. In the majority of schools, the core program is a basal reading program. Although the reading wars have lead to dramatic lurches in how reading is taught, basal reading programs have continued to be a prevalent force in a vast majority of American classrooms (Farr, Tulley, \& Powell, 1987; Hoffman et al., 1994). For example, Farr et al. (1987) reported that $80 \%$ to $90 \%$ of children learn to read in classrooms where a basal reading program is used. With No Child Left Behind (NCLB), the role of the basal reading textbook in early reading instruction has taken on even greater emphasis.

\section{Making Tier 1 Core Reading Instruction More Systematic and Explicit}

Systematic and explicit reading instruction has been embraced by virtually every authoritative analysis of beginning reading instruction (e.g., Adams, 1990; National Reading
Panel [NRP], 2000; Snow, Burns, \& Griffin, 1998). Core reading programs, particularly basal programs, have become more consistent in focusing on essential content (e.g., the five big ideas-phonological awareness, phonics, fluency, vocabulary, and comprehension) and focusing more intensively on helping teachers make that instruction more systematic and explicit. Based on our experience, during Tier 1 instruction, students with different reading ability and language proficiency levels are together in one group. Therefore, making Tier 1 instructional materials more focused and systematic helps all students, particularly those students at elevated risk for reading difficulty (Raudenbush, 2009).

As a framework for organizing the core reading materials in Tier 1 to make reading instruction more systematic and explicit, we have relied on six features of instructional design described by Carnine and his colleagues (Carnine \& Kame'enui, 1992; Chard \& Jungjohann, 2006; Coyne, Kame'enui, \& Carnine, 2006):

1. Learning strategies are made conspicuous through visual models, verbal directions, full and clear explanations, and outlined steps.

2. Instruction is integrated to build connections between new material and previously taught material.

3. Instruction activates background knowledge so that students have a way of integrating new knowledge.

4. Instructional scaffolds are provided and removed systematically as students take greater control of learning over time.

5. Sufficient practice to achieve automaticity is provided.

6. Previously learned material is reviewed systematically.

Table 1 presents a phonemic awareness activity drawn from a commonly used core reading program in first grade. The left side of the panel shows how the lesson is presented in the core program. The right side of the panel presents our recommendations for making instruction more systematic and explicit, following the framework of teachers clearly explaining or modeling the task and students overtly demonstrating their understanding. In the contrasted examples, four distinctions stand out.

\section{Interaction expectations between teachers and students}

One important difference is clarity in how teachers and students are expected to interact during the activity. In the standard example, little is specified and what is stated is not precise. Teachers introduce the lesson by saying, "We're going to play a guessing game," and then start the major part of the activity. Nothing about activity content is stated, nor is anything about the teacher or students' roles during the activity stated. This lack of specificity is common in core reading programs. As the lesson unfolds, students must infer the purpose of the activity by what the teacher tells them to do (not by what the teacher tells them the purpose is). Of course, many teachers will attempt to explain the purpose so 


\section{TABLE 1}

\section{Enhanced Phonemic Awareness Instruction in Tier 1}

Standard Teacher Directions
Daily Phonemic Awareness
Blending Phonemes:
Name the Picture
Tell children that they will play a
guessing game.

Hold up a picture card map so that children can't see the picture. Say the picture name, segmenting the sounds. Say: /m/ /a/ /p/. Repeat.

Have children guess the picture name by blending the sounds together, saying the word naturally to themselves and raising their hands when they know the word.

When all hands are up, show children the picture so that they can check the responses.

Repeat this activity with the picture cards bat, bus, can, cap, cup, dot, leg and nut.

\author{
Enhanced Teacher Directions
}

\section{Daily Phonemic Awareness \\ Say: You're going to practice blending individual sounds to make words. I'll tap a cube as I say each sound in the word. When I slide my finger above the cubes, you'll say the whole word.}

(Model only the first couple of times.)

Say: I'll model for you how to blend the sounds I say into a word. I'll model two words. My turn. $/ \mathrm{m} / / \mathrm{a} / / \mathrm{p} / \mathrm{map}, / \mathrm{b} / / \mathrm{a} / / \mathrm{t} /$ bat.

Model, using the signaling procedure above, with only teacher responding.

Say: Your turn. Use the signaling procedure above with only students responding. $/ \mathrm{m} / / \mathrm{a} / / \mathrm{p} /$

$/ \mathrm{b} / / \mathrm{a} / / \mathrm{t} /$

Repeat with bus, can, cap, cup, dot, let, and nut

To correct students:

Say: My turn. Use signaling procedure above with only teacher responding to correct students on missed item.

Say: Your turn. Use signaling procedure above with only students responding. Back up two words and continue.

When it appears that the group is consistently answering all items correctly, provide individual turns as a check. Call on several students for one word each. Call on students in an unpredictable order. Call more frequently on students who made errors. If a student makes an error on an individual turn, you may provide the correction procedure with all students responding. students understand the big picture. However, our experience is that impromptu teacher explanations vary in quality and can be unclear for many students. These types of explanations are surprisingly difficult to do clearly and succinctly, particularly on the fly.

In the enhanced example, teachers explain the purpose of the activity quickly, using precise wording, and then immediately provide a vivid demonstration of what they expect students to do during the activity. This sets the stage for accurate student responses. The explanation of what teachers will do during the activity and what students will do is clear. These two actions-teachers explaining the overall purpose of the task and modeling for students what they want students to be able to do-can be applied to any content area in early reading (it can also be applied with older students and across subject areas). In early reading, teachers can do this with lower level skills such as phoneme awareness and word reading, as well as with higher level skills such as vocabulary and comprehension.

\section{How students demonstrate their understanding}

Another important contrast is how students are expected to respond. In the standard example, teachers say the target sounds out loud, but students only blend these sounds and "say" the whole word to themselves. When they know what the word is they raise their hand. In other words, students do not actually have' to say anything during the activity if the teacher's guide is strictly followed. In phonemic awareness activities, where sound production and detection is critical, not requiring students to produce sounds or words verbally is a significant shortcoming (Torgesen et al., 1999).

In the enhanced example, students verbally blend all of the sounds in nine words, using group responding techniques. This explicit act, either done by a group of students or students individually, enables teachers to know whether students have learned what teachers expected them to learn. If the group of students is large, it is essential that teachers have some uniform way of getting students to know when they are supposed to respond. If students respond as soon as they know the answer, more advanced students will respond first, and less advanced students will frequently mimic the advanced students and not focus on the purpose of the lesson. In the enhanced example, the teachers use a precise signaling technique to indicate when students should respond. When response signals are used effectively, they look natural, and students like them because they know what is 
expected. With large groups of students, the alternatives either result in disorganized responses, if teachers try to give students the opportunity to respond verbally together, or in subvocal responses, where lesson quality is significantly compromised.

\section{How teachers provide feedback}

In the standard example, students confirm whether their answer is correct by comparing their unvoiced response to the picture displayed by the teacher. This approach has several problems. First, it is the students themselves who determine whether they are correct. These students are in first grade, and this may not be a good role for them during the initial stages of learning. Second, students have to compare their subvocal response to a picture. The purpose of the lesson is phonemic awareness, to blend sounds into words. Comparing a blended word to a picture introduces a task dimension that is extraneous to the lesson purpose. Some students may see pictures of the target words, for example, and not know the verbal label for the picture.

Another related shortcoming is that is the standard example provides no information about what teachers should do if they suspect students are responding incorrectly. If student responses are not correct, should they guess again? Should teachers model the right response and have students practice it right after them? Should they go on to the next word? Correcting students' errors and misunderstandings is an essential instructional element in early reading instruction (Carnine, Silbert, Kame'enui, \& Tarver, 2004; Gersten, Carnine, \& Woodward, 1987; Gersten, Carnine, \& White, 1984; Patching, Kame'enui, Carnine, Gersten, \& Colvin, 1983). Not providing information about how teachers are supposed to address or correct student errors creates extensive variability among teachers in how they address student errors. Some teachers may use very effective approaches, but others may not.

In the enhanced example, students respond out loud, which enables teachers to hear whether students are responding correctly. Tracking response accuracy when groups of students are responding can be tricky, but our experience is that most teachers can learn to do this accurately and effectively, and if they use clear response signaling procedures, they will be able to detect even subtle errors. Once teachers determine that a group or individual response is not correct, the enhanced lesson is clear about the specific error correction procedure teachers should use. Notice that teachers do not have to tell students they made an error. They simply interrupt the task, model the correct response, and make sure students demonstrate their understanding by producing the correct response after the correction.

This specific error correction procedure follows a general procedure teachers can use for any early reading instructional activity. The approach is to stop the lesson for a very short period of time, model the correct response, and have students produce the correct response (Carnine et al., 2004). An additional routine step is to come back to the original challenging problem a number of times before completing the lesson to make sure students are consistent. This error correction routine will look different for some higher order activities (Gersten \& Carnine, 1986). In a comprehension activity, where students are not able to identify the main idea, for example, a poor correction procedure would be for the teacher to simply tell students the main idea. A better procedure would be for the teacher to model "thinking aloud" to determine the main idea before stating what it is. This type of error correction will take longer than correcting a word reading error, of course, but the principle of addressing student errors and misunderstandings using a general routine is the same (Gersten \& Carnine, 1986).

\section{How much practice students get}

The final important difference is the amount and type of practice students receive. In the standard example, the students have nine opportunities in the activity to respond. In the enhanced example, students respond verbally to the same nine words, but, for each word, students get several additional response opportunities in the form of individual turns. If the teacher calls on two students per word (in an unpredictable order), the result would be an additional 18 responses. In the individual turns, of course, the richest opportunities go to the students who are called on to respond. In the enhanced example, teachers are encouraged to call on students who are struggling (e.g., Tier 2 students) more frequently than students who have no difficulty with the lesson (e.g., Tier 1 students). Also, however, effective teachers make sure that the students who are not called on are paying active attention so that, even though they are not responding verbally, they are formulating the answers and listening to the students who are responding.

The technique of using group response formats to allow many students to respond, followed by individual student responses, is a structure that can be used for many early reading activities. When overt responses with clear correct and incorrect answers are the target (e.g., phonemic awareness activities, word reading activities) the format presented here works well. If higher order responses are the target, in comprehension or vocabulary activities, for example, the same structure can be followed, but it may take a different shape. For instance, in the main idea example, a large group of students can work on several main idea examples together. All students might formulate answers, but individual students would be called on to share their answers. To give more practice to students in the form of individual responses, students might then work together in pairs to read sections of text and then practice forming the main idea and expressing it to their partner. At this point, the teacher could circulate around the room and pay particular attention to how well struggling students are doing with this main idea activity. 


\section{Summary of improving Tier 1 instruction}

The purpose of systematically modifying the lesson this way is to provide robust instruction for all students receiving Tier 1 instructional supports. In a typical classroom, this instruction is provided to those students who would normally receive Tier 1 supports and Tier 2 supports. For Tier 2 students, the ability to make Tier 1 instruction more systematic and explicit is critical. Without efforts to make Tier 1 instruction more robust, the time Tier 2 students spend receiving Tier 1 core instruction may not be of sufficient quality for them to make adequate progress - not only the progress necessary to keep up with their peers but also the accelerated progress necessary to close the reading gap. Robust Tier 1 instruction achieves the first step in establishing a solid reading program for Tier 2 students. The second essential step is to implement robust Tier 2 instruction daily for Tier 2 students.

\section{Small-Group Instruction in Tier 2}

The two primary differences between Tier 1 and Tier 2 instruction are (a) group size and (b) the intensity of students' instructional opportunities to learn essential content and receive high quality interactive instruction and feedback from teachers. The extent to which other elements of instruction can remain consistent across supports in Tiers 1 and 2 will help students focus on essential learning objectives. In other words, consistent instruction across tiers, in how teachers explain tasks and model for students, for example, and in how students are expected to respond and how teachers provide feedback, helps keep essential learning objectives in the forefront (Carnine, 1992). In the context of the framework proposed in this article, consistency in materials, content, and examples is also highly desirable.

Table 2 is an example of content from the core reading program that can be used during small-group instruction in Tier 2. This particular lesson is designed to occur early in the academic year. It covers 5 days and takes about 27 minutes per lesson. It is composed of nine instructional activities (listed across the top) targeting three major content areas: (a) phonemic awareness, (b) word reading, and (c) reading connected text.

A number of critical points about the content and structure of this 5-day sequence make this a potentially strong set of Tier 2 lessons. First, the content comes from the core program, so the material will have been taught in Tier 1. By increasing the instructional intensity in the small group format in Tier 2, students will have more time and robust opportunities to learn essential Tier 1 content.

Second, the design of the small-group activities is similar to the format used in many intervention studies targeting Tier 2 instruction (Gersten et al., 2008). The instruction is very explicit, it provides many practice opportunities for students, and the number and range of activities should facilitate a brisk pace to the lesson, thereby increasing student engagement and learning (Greenwood, Delquadri, \& Hall, 1984).

Third, the bulk of the instructional time is spent on reading connected text. In other words, although students do spend time practicing skills in isolation (a frequent criticism leveled against many explicit instruction methods), most of the instructional time is spent on reading stories containing words students had been taught to read previously as irregular words or words that contained letter-sound correspondences and thus could likely decode on their own.

One of the most important components of the lesson is not readily apparent in the table. Each activity in the lesson is taught using the same framework used by the teacher during Tier 1 instruction. In the series of Tier 2 lessons the teacher (a) explains and models the task, (b) provides opportunities for the students in the small group to practice the task with feedback, and (c) provides individual turns for students and opportunities for them to apply the lesson content on their own.

A great deal of detailed instructional information is presented in the Tier 2 example (Table 2). Clearly, if this material is not available in the core program, it will take time to develop. However, we believe the benefit to integrated instruction and student learning can be substantial when it is done effectively, and it is worth the investment of time and expertise to do it well. It is difficult to overestimate the importance of early reading instruction that focuses on the development of phonological awareness and alphabetic understanding (Adams, 1990; National Research Council [NRC], 1998; NRP, 2000). The opportunity to get this instruction right in terms of design and content should be an essential priority across state, district, and school levels. The effective integration of instructional support systems across Tiers 1 and 2 can be a major accomplishment toward this objective. The idea of this tight integration is also very relevant in higher order learning objectives, including vocabulary and comprehension.

\section{Integration of Tiers 1 and 2 Involving Higher Order Content}

In early reading, higher order content is typically associated with vocabulary and comprehension instruction. Regarding Tier 1 vocabulary instruction, core programs frequently either have teachers explain words in the reading selection only once or recommend what teachers can do with students to practice learning word meanings. For additional practice of key vocabulary words, students are directed to the practice book. The following directions for vocabulary instruction are taken from a core program in second grade and illustrate this type of approach:

Read aloud the first sentence on the transparency. Model how to use clues in the sentence to figure out what the word admire means. Have children identify context clues to the meaning of the key vocabulary words in the remaining 
TABLE 2

Scott Foresman Small Group Lesson - Unit 1, Week 2 - Target Skills

\begin{tabular}{|c|c|c|c|c|c|c|c|c|c|}
\hline \multicolumn{10}{|c|}{ Scott Foresman Small Group Lessons -- Unit 1, Week 2 -- Target Skills: } \\
\hline \multirow[t]{2}{*}{ Day: } & $\begin{array}{l}\text { Word Reading } \\
\text { Irregular } \\
\text { Card \#3 }\end{array}$ & $\begin{array}{c}\text { Phonemic } \\
\text { Awareness } \\
\text { Card \#5 }\end{array}$ & $\begin{array}{c}\text { Phonemic } \\
\text { Awareness } \\
\text { Card \#6 }\end{array}$ & $\begin{array}{c}\text { Teach } \\
\text { Sound/ } \\
\text { Spelling } \\
\text { Card \#7 }\end{array}$ & $\begin{array}{l}\text { Blending } \\
\text { Practice } \\
\text { Card \#8 }\end{array}$ & $\begin{array}{l}\text { Word Reading } \\
\text { Regular } \\
\text { Card \#3 }\end{array}$ & $\begin{array}{l}\text { Decodable Text } \\
\text { Reading } \\
\text { Card \#11 or \#12 }\end{array}$ & Dictation & $\begin{array}{l}\text { Reteaching } \\
\quad \text { or } \\
\text { Rereading }\end{array}$ \\
\hline & (1 minute) & (1 minute) & (1 minute) & (2 minutes) & (2 minutes) & (1 minute) & (15 minutes) & (7 minutes) & (7 minutes) \\
\hline $\begin{array}{c}\text { Day } \\
1\end{array}$ & $\begin{array}{l}\text { and play up way } \\
\text { on take play and } \\
\text { in on and take } \\
\text { take up in on }\end{array}$ & 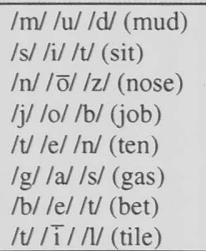 & $\begin{array}{l}\text { fog } / \mathrm{ff} / / \mathrm{o} / / \mathrm{g} / \\
\text { nice } / \mathrm{n} / / \overline{\mathrm{i}} / / \mathrm{s} / \\
\operatorname{ran} / \mathrm{r} / / \mathrm{a} / / \mathrm{n} / \\
\operatorname{pup} / \mathrm{p} / / \mathrm{u} / / \mathrm{p} / \\
\text { ton } / \mathrm{t} / / \mathrm{o} / / \mathrm{n} / \\
\text { mat } / \mathrm{m} / / \mathrm{a} / / \mathrm{t} / \\
\text { need } / \mathrm{n} / / \overline{\mathrm{e}} / / \mathrm{d} / \\
\operatorname{rose} / \mathrm{r} / / \overline{\mathrm{o}} / / \mathrm{z} /\end{array}$ & $\begin{array}{lllll} & \text { a } & x & c k \\
c k & x & a & i \\
a & i & x & w \\
x & v & i & c k\end{array}$ & $\begin{array}{l}\text { wax mix } \\
\text { six lid } \\
\text { tan tap } \\
\text { mat nab } \\
\text { pig rib } \\
\text { if in }\end{array}$ & $\begin{array}{l}\text { fix sax wax mix } \\
\text { six kick pack back } \\
\text { fax pick quick Max } \\
\text { rack lick sax }\end{array}$ & $\begin{array}{l}\text { Decodable } \\
\text { Reader \#4 }\end{array}$ & $\begin{array}{l}\text { mix } \\
\text { wax } \\
\text { pig } \\
\text { rib } \\
\text { lid } \\
\text { pick }\end{array}$ & \\
\hline $\begin{array}{c}\text { Day } \\
2\end{array}$ & $\begin{array}{l}\text { play take in and } \\
\text { on play and way } \\
\text { way take in play } \\
\text { and in take on }\end{array}$ & $\begin{array}{l}/ \mathrm{t} / \mathrm{i} / / \mathrm{m} / \text { (time) } \\
/ \mathrm{b} / / \mathrm{a} / / \mathrm{l} / \text { (bat) } \\
/ \mathrm{h} / / \mathrm{u} / / \mathrm{g} / \text { (hug) } \\
/ \mathrm{r} / / \overline{\mathrm{a}} / / \mathrm{h} / \text { (rain) } \\
/ \mathrm{p} / / \mathrm{o} / / \mathrm{p} / \text { (pop) } \\
/ \mathrm{d} / / \mathrm{i} / \mathrm{g} / \text { (dig) } \\
/ \mathrm{r} / / \mathrm{e} / \mathrm{d} / \text { (red) } \\
/ \mathrm{l} / \mathrm{i} / / \mathrm{p} / \text { (lip) }\end{array}$ & $\begin{array}{l}\text { him } / \mathrm{h} / / \mathrm{i} / / \mathrm{m} / \\
\text { same } / \mathrm{s} / / \overline{\mathrm{a}} / / \mathrm{m} / \\
\text { bat } / \mathrm{b} / / \mathrm{a} / / \mathrm{t} / \\
\text { cope } / \mathrm{k} / / \overline{\mathrm{o}} / / \mathrm{p} / \\
\text { cat } / \mathrm{k} / / \mathrm{a} / / \mathrm{t} / \\
\text { time } / \mathrm{t} / / \overline{\mathrm{i}} / / \mathrm{m} / \\
\text { sit } / \mathrm{s} / / \mathrm{i} / / \mathrm{t} / \\
\text { leg } / \mathrm{l} / \mathrm{e} / / \mathrm{g} /\end{array}$ & $\begin{array}{llll}x & c k & i & a \\
c k & i & a & x \\
x & c k & y & i \\
a & x & i & z\end{array}$ & $\begin{array}{l}\text { tick pick } \\
\text { hip sad } \\
\text { bag tick } \\
\text { can dig } \\
\text { tip if } \\
\text { fin man }\end{array}$ & $\begin{array}{l}\text { and take up what } \\
\text { she that there you }\end{array}$ & $\begin{array}{l}\text { Student } \\
\text { Selection: } \\
\text { Pig in a Wig } \\
\end{array}$ & $\begin{array}{l}\text { hip } \\
\text { tick } \\
\text { man } \\
\text { dig } \\
\text { bag } \\
\text { pick }\end{array}$ & \\
\hline $\begin{array}{c}\text { Day } \\
3\end{array}$ & $\begin{array}{l}\text { get play help up } \\
\text { and get help take } \\
\text { and help on get } \\
\text { in play take way }\end{array}$ & $\begin{array}{l}/ \mathrm{m} / / \mathrm{a} / / \mathrm{t} / \text { (mat) } \\
/ \mathrm{s} / / \mathrm{u} / / \mathrm{n} / \text { (sun) } \\
/ \mathrm{d} / / \mathrm{e} / / \mathrm{d} / \text { (deed) } \\
/ \mathrm{l} / \mathrm{a} / / \mathrm{p} / \text { (lap) } \\
/ \mathrm{r} / / \mathrm{i} / / \mathrm{d} / \text { (rid) } \\
/ \mathrm{s} / / \mathrm{u} / / \mathrm{m} / \text { (sum) } \\
/ \mathrm{p} / / \mathrm{e} / / \mathrm{n} / \text { (pen) } \\
/ \mathrm{f} / / \mathrm{\overline {o }} / / \mathrm{n} / \text { (phone) }\end{array}$ & $\begin{array}{l}\text { knot } / \mathrm{n} / / \mathrm{o} / / \mathrm{l} / \\
\text { lap } / \mathrm{l} / / \mathrm{a} / / \mathrm{p} / \\
\text { sun } / \mathrm{s} / / \mathrm{u} / / \mathrm{n} / \\
\operatorname{deed} / \mathrm{d} / / \overline{\mathrm{e}} / / \mathrm{d} / \\
\text { life } / \mathrm{l} / / \mathrm{i} / / \mathrm{f} / \\
\text { can } / \mathrm{k} / / \mathrm{a} / / \mathrm{n} / \\
\operatorname{mean} / \mathrm{m} / / \overline{\mathrm{e}} / / \mathrm{n} / \\
\text { bin } / \mathrm{b} / / \mathrm{i} / / \mathrm{n} /\end{array}$ & $\begin{array}{llll}\mathrm{x} & \mathrm{i} & \mathrm{x} & \mathrm{o} \\
\mathrm{x} & \mathrm{o} & \mathrm{i} & \mathrm{ck} \\
\mathrm{o} & \mathrm{i} & \mathrm{a} & \mathrm{x} \\
\mathrm{i} & \mathrm{o} & \mathrm{x} & \mathrm{ck}\end{array}$ & $\begin{array}{l}\text { six fix } \\
\text { lit pig } \\
\text { sit and } \\
\text { lip jab } \\
\text { nab pack } \\
\text { Jack kid }\end{array}$ & $\begin{array}{l}\text { bag nap in can } \\
\text { Matt ran on tan } \\
\text { sack back Dad pack } \\
\text { van }\end{array}$ & $\begin{array}{l}\text { Selection: } \\
\text { We Are Vets }\end{array}$ & $\begin{array}{l}\text { bag } \\
\text { back } \\
\text { six } \\
\text { on } \\
\text { nap } \\
\text { and }\end{array}$ & \\
\hline $\begin{array}{c}\text { Day } \\
4\end{array}$ & $\begin{array}{l}\text { mud play help town } \\
\text { get town help mud } \\
\text { and mud town get } \\
\text { in up take way }\end{array}$ & $\begin{array}{l}/ \mathrm{m} / / \mathrm{l} / / \mathrm{d} /(\mathrm{mad}) \\
/ \mathrm{n} / / \overline{\mathrm{e}} / / \mathrm{d} /(\text { need) } \\
/ \mathrm{s} / / \overline{\mathrm{o}} / / \mathrm{k} /(\text { (soak) } \\
\mathrm{It} / \mathrm{a} / / \mathrm{n} /(\tan ) \\
/ \mathrm{d} / / \mathrm{o} / / \mathrm{g} /(\mathrm{dog}) \\
/ \mathrm{s} / / \mathrm{i} / / \mathrm{t} /(\mathrm{sit}) \\
/ \mathrm{r} / / \mathrm{u} / / \mathrm{n} /(\mathrm{run}) \\
/ \mathrm{T} / / \mathrm{e} / / \mathrm{g} /(\mathrm{leg})\end{array}$ & $\begin{array}{l}\text { name } / \mathrm{n} / / \overline{\mathrm{a}} / / \mathrm{m} / \\
\text { run } / \mathrm{r} / / \mathrm{u} / / \mathrm{n} / \\
\text { mom } / \mathrm{m} / / \mathrm{o} / / \mathrm{m} / \\
\text { line } / \mathrm{l} / / \overline{\mathrm{i}} / / \mathrm{n} / \\
\text { cap } / \mathrm{k} / / \mathrm{a} / / \mathrm{p} / \\
\text { his } / \mathrm{h} / / \mathrm{i} / / \mathrm{s} / \\
\operatorname{coat} / \mathrm{k} / / \bar{\sigma} / / \mathrm{t} / \\
\text { map } / \mathrm{m} / / \mathrm{a} / / \mathrm{p} /\end{array}$ & $\begin{array}{llll}0 & i & a & x \\
i & x & o & a \\
c k & o & x & i \\
i & x & o & c k\end{array}$ & $\begin{array}{l}\text { Bob box } \\
\text { on block } \\
\text { Dot fox } \\
\text { hop hot } \\
\text { rib sit } \\
\text { tin tap }\end{array}$ & & $\begin{array}{l}\text { Strategic } \\
\text { Decodable } \\
\text { Reader \#2 }\end{array}$ & $\begin{array}{l}\text { sit } \\
\text { box } \\
\text { tin } \\
\text { block } \\
\text { tap } \\
\text { rib }\end{array}$ & \\
\hline $\begin{array}{c}\text { Day } \\
5\end{array}$ & $\begin{array}{l}\text { use get help play } \\
\text { mud take use up } \\
\text { town and mud use } \\
\text { way town get help }\end{array}$ & $\begin{array}{l}/ \mathrm{n} / / \mathrm{o} / / \mathrm{t} / \text { (not) } \\
/ \mathrm{b} / / \mathrm{a} / / \mathrm{g} / \text { (bag) } \\
/ \mathrm{s} / / \mathrm{i} / / \mathrm{p} / \text { (sip) } \\
/ \mathrm{d} / / \mathrm{e} / / \mathrm{d} / \text { (deed) } \\
/ \mathrm{f} / / \mathrm{u} / / \mathrm{n} / \text { (fun) } \\
/ \mathrm{k} / / \mathrm{o} / / \mathrm{p} / \text { (cop) } \\
/ \mathrm{f} / / \overline{\mathrm{o}} / / \mathrm{n} / \text { (phone) } \\
/ \mathrm{r} / / \overline{\mathrm{a}} / / \mathrm{n} / \text { (rain) }\end{array}$ & $\begin{array}{l}\text { sad } / \mathrm{s} / / \mathrm{a} / / \mathrm{d} / \\
\text { pen } / \mathrm{p} / / \mathrm{e} / / \mathrm{n} / \\
\text { time } / \mathrm{t} / / \mathrm{i} / / \mathrm{m} / \\
\text { tug } / \mathrm{t} / / \mathrm{u} / / \mathrm{g} / \\
\text { jog } / \mathrm{j} / / \mathrm{o} / / \mathrm{g} / \\
\text { late } / \mathrm{l} / / \overline{\mathrm{a}} / / \mathrm{t} / \\
\text { sock } / \mathrm{s} / / \mathrm{o} / / \mathrm{k} / \\
\text { rid } / \mathrm{r} / / \mathrm{i} / / \mathrm{d} /\end{array}$ & 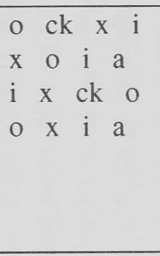 & $\begin{array}{l}\text { Pop rob } \\
\text { lot not } \\
\text { sick snack } \\
\text { hip hit } \\
\text { had ham } \\
\text { mad tack }\end{array}$ & $\begin{array}{l}\text { fox mop rock top } \\
\text { not ran sat am } \\
\text { back wax bag lid } \\
\text { hop six van }\end{array}$ & $\begin{array}{l}\text { Decodable } \\
\text { Reader \#5 }\end{array}$ & $\begin{array}{l}\text { rob } \\
\text { six } \\
\text { fox } \\
\text { back } \\
\text { lot } \\
\text { wax }\end{array}$ & \\
\hline
\end{tabular}


sentences. Then have children complete pages 179-181 in their Practice Book independently.

Extensive vocabulary research provides clear guidelines for the type of robust vocabulary instruction that should be incorporated in all tiers of support, including Tier 1 (Baker, Simmons, \& Kame'enui, 1995; Baker, Simmons, \& Kame'enui, 1998; Baumann \& Kame'enui, 1991; Baumann, Kame'enui, \& Ash, 2003; Beck, McKeown, \& Kucan, 2008; Biemiller, 2001; Graves, 2006). Effective vocabulary instruction should be a central focus in any content area, including early reading. We have a strong knowledge base on how to teach word meanings to students, including directly teaching students word meanings on a daily basis. We know, for example, that explicit vocabulary instruction should target the most important words students should know, words that students should be able to use across multiple contexts. Words should be defined for students in ways they understand, with multiple examples and nonexamples of appropriate use in authentic contexts. Students need numerous exposures to words across time and contexts and opportunities to work with words in meaningful ways if we expect them to use new words on their own.

In Table 3, we provide a framework for vocabulary instruction for the word admire that builds on the example from the Tier 1 program. This type of instruction can form the basis of solid vocabulary instruction in Tiers 1 and 2 . Similar to the phonemic awareness and alphabetic understanding example presented earlier, the major differences in Tier 2 are the smaller group size and the instructional opportunities afforded for more intense instructional interactions. This might include the use of instructional scaffolds to make abstract concepts more concrete for learners. For example, Tier 2 might also include the regular creation and use of procedural facilitators, including semantic maps and other graphic depictions of word meanings and taxonomies, which would help students deepen their knowledge of word meanings (Baker, Gersten, \& Scanlon, 2002; Gersten, Baker, Pugach, Scanlon, \& Chard, 2001).

Table 3 presents an instructional sequence that is aligned with key principles of high quality vocabulary instruction (e.g., Archer, 2006; Baumann et al., 2003; Beck, McKeown, \& Kucan, 2002; Graves, 2006). The following principles are evident in the example: (a) It teaches a student-friendly definition of the target word, (b) it provides examples of the word in contexts that are meaningful for students, (c) students discriminate between correct and incorrect applications of the word, (d) with a partner or on their own students create additional examples of applying the word in appropriate contexts, and (e) students are encouraged to use the target word outside of instructional time. What is not apparent in the figure is that high quality vocabulary instruction in any tier should include extensive review of previously learned words.

\section{Providing students with clear definitions of word meanings}

In the standard activity, the teacher is expected to model how to use clues to understand the meaning of admire. Asking students to use clues to define words can be a useful approach (Jenkins, Stein, \& Wysocki, 1984). However, the program should guide teachers on how to use a think-aloud technique to model for students how to do this (Gersten, Baker, \& Marks, 1998). Without clear examples of how to use clues to determine word meanings (it is a difficult thing to teach, especially spontaneously), the lesson can meander or be confusing for students. Irrelevant teacher talk may increase when teachers have no real framework to follow, and, as a result, students might miss essential content, such as getting a clear definition of the target word. In the enhanced example, the teacher defines the word admire and uses examples to illustrate the definition before asking students to do anything with the word (either define it or use it). Words with which most second grade students will be familiar are used to define admire.

Frequently during vocabulary instruction, teachers ask students what a word means, and if students answer correctly, they move on to the next word. Asking students to explain the meaning of words is appropriate if they know the meaning (e.g., as a review activity), but for students who lack this knowledge, learning the meaning from a brief explanation by a peer is unlikely to give them much understanding. When teachers make sure students get a good definition of key vocabulary words and hear how they are used in sentences, it is much more likely that students who had no knowledge of the target words before the lesson began will have a much better understanding after the lesson (Beck et al., 2008).

\section{Giving examples of the word in meaningful contexts for students}

In the enhanced activity, examples of how admire is used are related to family, friends, and to the reading selection students are working on at that moment. This helps ensure that students will gain an understanding of the word in the context of things they know (i.e., family, friends) or things they are expected to know (i.e., story content). Seeing vocabulary words applied to what students know increases the likelihood that they will also use the word when they themselves speak or write. An important characteristic of deep word knowledge is knowing when words are applied or used correctly and when they are not. Working with correct and incorrect applications of word meanings (i.e., examples and nonexamples) helps students learn to discriminate when and how to use new vocabulary.

\section{Having students work with word meanings in pairs or on their own}

To deepen word knowledge, planned opportunities for students to apply new vocabulary are very important. These 


\section{TABLE 3}

\section{Enhanced Vocabulary Instruction for Tier 1 Second Grade}

\begin{tabular}{|c|c|}
\hline Theme: People & Word: Admire \\
\hline \multirow[t]{5}{*}{$\begin{array}{l}\text { Introduction of } \\
\text { the word }\end{array}$} & $\begin{array}{l}\text { T: The word you are going to learn is admire. Say the word with me: admire. } \\
\text { (Use similar signaling procedures as with phonemic awareness activities.) }\end{array}$ \\
\hline & Ss: admire \\
\hline & $\begin{array}{l}\text { T: The sounds in admire are: /a/ /d/ / } / \mathrm{m} / / \text { ai } / / \mathrm{r} / \text {. Can you tell me all the sounds in admire? } \\
\text { (Use similar signaling procedures as with phonemic awareness activities.) }\end{array}$ \\
\hline & Ss: /a/ /d/ / $/ \mathrm{m} / /$ ail/ $/ \mathrm{r} /$ \\
\hline & $\begin{array}{l}\text { T: Yes, the sounds are: /a/ /d/ / } / \mathrm{m} / / \mathrm{ai} / / \mathrm{r} / \text { Here is how you spell admire: ( }(\mathrm{writes} \text { word on the } \\
\text { board) }\end{array}$ \\
\hline
\end{tabular}

Studentfriendly definition
T: Admire means to like and respect someone. Listen again: Admire means to like and respect someone. Admire means what? (Use similar signaling procedure as above to ensure students respond in unison).

Ss: ... to like and respect someone.

Examples

T: I will give you examples of the word admire: My mother always makes delicious dinners. I admire her because she is a very good cook.

T: Watch how I will use the word admire that was in the story we just read: Tomie de Paola always wanted to be an artist. I admire him because he didn't give up on his dream to become an artist.

T: Here is another example of admire: My best friend was kicked by another kid. My best friend did not kick him back but went to the principal and told him what had happened. I admire my best friend because he did not kick back.

Discrimination

T: When I signal, give me thumbs up or thumbs down if the sentence matches the definition of admire. When you admire someone, you:

respect them by saying good things about them (Signal) ....................Ss: thumbs up

say bad things about them (Signal)..................................................Ss: thumbs down

yell at them (Signal) ........................................................................Ss: thumbs down

hang a picture of them on the wall (Signal)..........................................Ss: thumbs up

listen to what they say (Signal) ...........................................................

Yes, admire means that you like and respect someone.

Building

Sentences
T: Now think of a person you admire. I will give you an example:

My turn: I admire Amelia Earhart because she was the first woman to fly around the world. Tell your partner about a person you admire. Start your sentence by saying:

I admire because Go.

Review

$\mathrm{T}$ : I want you to use the word admire when appropriate. When you have a sentence with admire, tell it to me, so we can add it to our Word Wall examples.

When students are working in pairs, the teacher moves around the classroom to make sure students are providing appropriate examples. Teacher guides students on how to use the word appropriately. Example:

S: I admire my mother because she says "hi" to me every morning.

T: The word admire means to like and show respect to someone for something special that they do. For example, I admire my mother because she always wakes up happy and kisses and hugs me every day even when she is very tired. Can you think of something else that your mother does that is special?

S: I admire my mother because she never gets mad at my little brother when he cries.

$\mathrm{T}$ : Yes, that is a good example of the word admire. 
activities give teachers a clear way to determine how well students understand the meaning of taught vocabulary. For application activities generally and for vocabulary words in particular, partner work is very effective. Structured work between peers both increases the meaningful engagement of all students and provides important practice opportunities, a key objective of moving toward independent student use of new vocabulary (Fuchs, Fuchs, \& Burish, 2000). While students are working with their peers, the teacher's responsibility is to circulate around the classroom, monitoring students and providing feedback on effort and content use.

\section{Encouraging students to use the word whenever appropriate}

The teacher uses an example from the reading selection to draw students' attention to the meaning of admire. In reality, it is not necessary for the reading selection to actually contain the word the teacher is drawing attention to, but doing so may help accomplish two important instructional objectives. First, it allows teachers to model for students how to make connections (in this case between an important vocabulary word and a story the class is reading), a key principle of academic learning that teachers want to reinforce as much as possible. Second, it uses an important vocabulary word in the context of academic content students can understand and should be working with in a variety of contexts. Also, in the context of vocabulary goals in particular, teachers should be vigilant about ways to use new vocabulary in a variety of contexts, including text selections, and they should regularly encourage students to use key vocabulary on their own (Beck et al., 2008).

\section{Error correction}

Correcting student errors and misunderstandings is a major aspect of strong vocabulary instruction. Effective teachers correct errors in ways that are not embarrassing for students and do not single them out. In the enhanced vocabulary example, we use an error correction procedure that is consistent with principles of effective instruction and similar structurally to the error correction procedure used in the phonemic awareness and decoding lesson. In essence, teachers provide feedback to students by modeling the correct use of the word.

In providing feedback, teachers can use ideas from students to support the use of admire in meaningful contexts. In the example, the teacher uses the same character (i.e., the mother) and the same timeline (i.e., every morning or every day) to create a sentence with admire, supporting students' attempts at meaningful comprehension. This type of teaching is masterful. It is very difficult to do well and smoothly, in part because no explicit or partial script can be relied on and in part because it requires teachers to build on what students themselves come up with. Particularly with higher order skills, frameworks like the one presented for vocabulary become springboards for highly interactive academic discourse (Beck \& McKeown, 2006; Goldenberg \& PattheyChavez, 1995).

\section{Reviewing words previously taught on an ongoing basis}

Systematic and frequent review is an essential instructional objective for all students, but it is particularly critical with students who are receiving instructional support in Tiers 2 and 3. Teachers should have a clear plan for review, including knowing which words will be reviewed and when. Part of effective vocabulary instruction, and a feature that greatly facilitates effective review, is to have vocabulary words on prominent visual display for students so they can be referred to during structured review opportunities. Also, having words visually available means students can refer to them whenever they want.

\section{Summary of Key Vocabulary Instruction}

Our experience is that without a lot of support for teachers, highly effective vocabulary instruction in Tier 1 is very difficult to provide. Developing effective vocabulary and comprehension activities can be extremely time consuming, and ideally a group of teachers in the school or district should develop these activities together to share the workload and ensure that all students are learning similar words in each grade (Gersten et al., 2007). If high-quality vocabulary instruction were provided consistently across all early reading instruction in a district, for example, it could significantly increase word learning outcomes for all students. In particular, integrating high quality vocabulary instruction across Tiers 1 and 2 would be beneficial for at-risk students and English learners (ELs). This type of deep and widespread implementation would require a significant districtwide commitment.

Just because students appear to be on track for developing foundational reading skills does not mean they have the language and vocabulary skills to learn and understand grade level content through their own reading and other ways. Vocabulary and comprehension instruction in the context of Tier 2 is appropriate for students with strong decoding skills but who would benefit from additional vocabulary and comprehension instruction. The challenge of understanding complex content, of course, becomes greater as students move up in grade. And just because students appear to be on track with foundational reading skills in the early grades is certainly no guarantee they will have the language and vocabulary skills necessary to deeply understand complex academic content (Biancarosa \& Snow, 2006; Kamil et al., 2008). ELs, for example, might particularly benefit from integrated Tier 2 instruction, where the focus during small group instruction is on previewing the vocabulary and comprehension lesson the teacher will teach during Tier 1 or reviewing the vocabulary and comprehension lessons previously taught during Tier 1 (Gersten et al., 2007). 


\section{DETERMINING THE EFFECTIVENESS OF INSTRUCTIONAL TIERS}

A critical component of RtI as a prevention and intervention system is using data to inform instructional decision making. One major aspect is determining the effectiveness of instruction within each tier, to distinguish efficacious practices from practices that require modification. In the framework we propose, this requires analysis and interpretation of two types of data sources.

\section{Student response data}

The first is student reading data, particularly student response data. We use the term response data in the context of Response to Intervention, to clearly indicate we mean growth over time (Francis, Fletcher, Stuebing, Davidson, \& Thompson, 1991). Measuring response (i.e., growth) directly takes into account how well students are reading at the end of the school year, for example, given their initial reading performance at the beginning of the school year (Baker et al., 2008). Performance data, on the other hand, can have a more specific meaning targeting how well students are reading at any point in time (e.g., their level of reading performance at the beginning of the school year or at the end of the school year). Performance data is also used more generally to describe data from a variety of sources that summarizes reading proficiency overall. Schools can use student response data to analyze how well their tiers of instructional support have systematically (a) decreased the percentage of students at the highest level of reading risk within and across school years, (b) increased the percentage of students who reach grade-level reading goals, and (c) increased strong rates of student reading growth and improvement over a specified time period (Baker et al., 2007).

\section{Classroom implementation data}

The second data source that can be used to examine the effectiveness of instructional tiers is classroom implementation data. Given the primacy of high quality instruction and intervention in RtI, we believe it is the responsibility of districts and schools to collect and summarize classroom implementation data regularly. Schools and districts should use reliable and valid implementation data to develop and refine their tiers of support over time.

We suggest that three sources of data can be central to improving the implementation of effective instruction over time. First, a document that codifies the primary features of each instructional tier should be developed and reviewed by key stakeholders (e.g., parents, school board members). This plan should include elements such as allocated time for reading instruction, grouping arrangements, methods of progress monitoring, and types of teaching strategies and methods. We refer to this as an instructional support plan.

Second, a standardized procedure should be used to determine the extent to which instruction specified in the instructional support plan is actually being provided in classrooms. This is aligned with the concept of the enacted curriculum versus the intended curriculum (Porter \& Smithson, 2001). This procedure should include classroom observations of fidelity of implementation (Gersten, Chard, et al., 2000).

Third, another type of standardized classroom observation procedure should be used to examine the extent to which an integrated set of evidence-based teaching practices is being used in the classroom (Pianta \& Hamre, 2009) that goes beyond fidelity of implementation of a specific program. These observations should help determine how effective teacher explanations and models are, how useful teacher academic feedback is, and how well teachers use students' ideas and responses as springboards for deep learning opportunities and rich academic interactions. This type of dynamic instruction, certainly the key features of it (e.g., high quality feedback, clear explanations), can be included and partially operationalized in the instructional support plan. However, this type of instruction is a delicate blend of the art and science of teaching, and it will take very knowledgeable school personnel to determine how well teachers are delivering this type of instruction and what constitute reasonable (challenging yet achievable) goals for teacher improvement.

These three data sources provide the basis for determining how the instructional tiers are supposed to differ and actually do differ, particularly in relation to instructional intensity. That is, the instructional support plan describes what should occur in each tier, and data related to fidelity of implementation and quality of instruction help determine what is actually occurring in the classroom. Together, the triangulation of the three data sources (Bogdan \& Biklen, 2006; Cohen, Manion, \& Morrisson, 2000) can increase the evidentiary basis for decisions made to improve instruction over time.

Ultimately, implementation data should be analyzed in conjunction with student reading data, particularly student response data indicating how much growth students have made over time. Student reading data and implementation data should be examined regularly throughout the school year to identify areas where instructional modifications are needed. These modifications should be reflected in an updated instructional support plan. In this way, the instructional support plan is a dynamic document that changes regularly in relation to the ongoing collection of student reading and implementation data.

\section{Student Reading Data}

Formative reading data collected during benchmarking assessments-universal assessments typically conducted at the beginning (e.g., fall), middle (e.g., winter), and end of the year (e.g., spring) - provide an excellent way to analyze the percentage of students who make adequate reading 
progress during the year (i.e., student response to instruction and intervention). School and district teams can use these data to evaluate the effectiveness of their instructional tiers. In the section that follows, we describe the logic of this approach and how we have used it with schools in the past. The data in our example come from 33 schools that participated in a federal reading initiative (i.e., RF; Baker et al., 2007, in press). All 33 schools received extensive professional development and onsite coaching to implement a tiered model of reading instruction that corresponds to the principles we have described in this paper. Each school used DIBELS (Good, Gruba, \& Kaminski, 2001) as their formative benchmarking assessment system with all $\mathrm{K}-3$ students three times per year. This process can, however, be applied to other benchmarking systems (e.g., CBM-R, Aimsweb, easyCBM).

We provide two examples for evaluating the effectiveness of tiers of instructional support for students. In the first, we focus on the percentage of student making adequate progress across the entire school year. In the second, we examine adequate progress over consecutive benchmarking time periods within a school year (e.g., progress from the beginning of the year [fall] to the middle of the year [winter]).

In the first example, the progress of each student was determined to be adequate or not adequate over the entire school year. Progress was adequate if the student began the school year with:

1. a benchmark instructional recommendation (i.e., at low risk for reading difficulty based on DIBELS screening measures) and ended the year at grade level reading performance on a comprehensive measure of reading (i.e., above the 40 th percentile on the SAT-10),

2. a strategic instructional recommendation (i.e., at some risk for reading difficulty based on DIBELS screening measures) and ended the year at grade level reading performance on a comprehensive measure of reading (i.e., above the 40 th percentile on the SAT-10), and

3. an intensive instructional recommendation (i.e., at high risk for reading difficulty based on DIBELS screening measures) and ended the year reading either at grade level (i.e., above the 40th percentile on the SAT-10) or somewhat below grade level (between the 20th and 40th percentiles on the SAT10) on a comprehensive measure of reading.

These definitions of adequate reading progress all increase the likelihood that a student will be a successful reader at the end of third grade. For students at moderate or high risk for reading difficulties, adequate progress reflects a meaningful reduction in the degree of reading risk from the beginning to the end of the school year. For students who are reading at the benchmark level of performance at the beginning of the year and receive Tier 1 supports, adequate progress indicates that their reading proficiency has improved enough to maintain their status of reading at the benchmark level, and they are reaching grade level reading expectations. For students who are reading at the strategic instructional level at the beginning of the year and receive both Tier 1 and Tier 2 instructional supports, adequate progress reflects that they have reached grade level reading expectations. For students who are intensive at the beginning of the year, instructional support may come in different combinations of Tiers 1, 2, and 3, depending on the school. For these students, adequate progress to the end of the year reflects a reduction in the degree of risk they face for longterm reading difficulties.

\section{Student response across the entire school year}

Table 4 presents one source of evidence we use to consider how effective different tiers of instructional support have been for students in first grade. In relation to student reading, two concepts are important in evaluating the effectiveness of any given tier of support: the reduction of risk for students at moderate or high risk (i.e., strategic and intensive at the beginning of the year) and keeping students who are already meeting grade level objectives (low risk, benchmark at the beginning of the year) on track to meet subsequent reading objectives.

To provide some context for understanding this analysis, consider that, in kindergarten the previous year, all students began the year by receiving Tier 1 core instruction. In the middle of the year, the students reading at benchmark levels of performance (i.e., considered to be on track for grade level reading outcomes) continued to receive only Tier 1 core instruction. Those students who were somewhat below benchmark levels of performance (i.e., moderate risk) received Tier 1 and Tier 2 supports, and students who were well below benchmark levels of performance (i.e., high risk) received Tier 3 support. In most schools, Tier 3 instruction was a replacement core program, meaning these students received virtually all of their instruction in a Tier 3 program (i.e., they received little or no reading instruction in the core Tier 1 program). The monitoring of student performance and flexibly grouping and regrouping students to match instruction with need continued throughout kindergarten. At the beginning of first grade, all students were screened for reading problems.

Table 4 presents how well these students learned to read in grade 1 . The left column shows the instructional recommendation at the beginning of the year and the number and percentage of students in each of the three categories. For example, at the beginning of first grade, $29 \%$ of the students in these schools began the year at high risk for long-term reading difficulties (i.e., intensive), $28 \%$ began at moderate risk (i.e., strategic), and $43 \%$ began at low risk (i.e., benchmark). Students at the benchmark level at the beginning of 


\section{TABLE 4 \\ Percentage of Students Reading at Different Levels on the SAT-10 Based on Beginning of Year DIBELS Instructional Recommendation (Cohort A First Grade Students in 2008)}

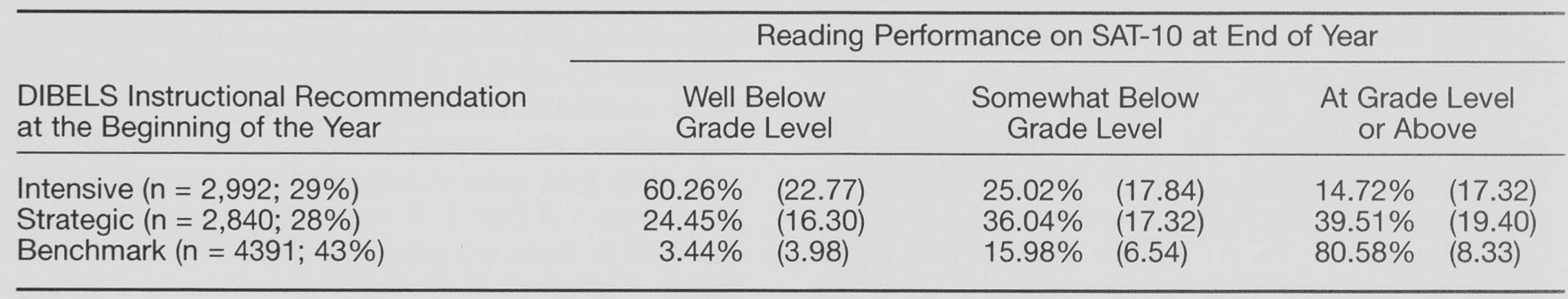

Note. Each cell represents the mean and standard deviation of 33 school percentages.

the year received core Tier 1 instructional supports. Students at the strategic level received Tier 1 and Tier 2 instructional supports, and students at the intensive level received Tier 3 instructional support.

The percentages in the table show how well students were reading at the end of the year in relation to their instructional recommendation at the beginning of the year. For example, of the 4,391 students who began the year at benchmark (i.e., on track for grade level reading outcomes), approximately $81 \%$ reached the SAT- 10 score used to define grade level reading proficiency (i.e., the 40th percentile or better).

These percentages provide a way to consider the effectiveness of the Tier 1 instructional support system. For example, if $100 \%$ of the students who began the year receiving only Tier 1 support reached the end-of-year reading goals, it would be reasonable to conclude the evidence strongly indicates Tier 1 was effective for students receiving just Tier 1 support. If, on the other hand, $25 \%$ of the students reached the end-of-year goals, this conclusion would not be warranted. The fact that about $81 \%$ of the students reached the end-of-year goal suggests a reasonable conclusion lies somewhere in between. That is, the Tier 1 instructional support system was effective for many low risk students but not for all low risk students.

It is critical to emphasize that these data reflect averages across all 33 schools. Examining the range of performance across individual schools presents a more nuanced and important story. For benchmark students in the top quartile schools, on average, $92 \%$ reached the end-of-year reading goals. For benchmark students in bottom quartile schools, on average, $70 \%$ reached the end-of-year reading goals. In a handful of schools, fewer than $65 \%$ of the students who began the year at benchmark reached the end-of-year reading goals. Clearly, schools differed widely in how effective their Tier 1 instructional system was for benchmark students. Evidence for the variability among schools in the pathways from student initial reading skill (i.e., benchmark, strategic, or intensive) towards end-of-year proficiency levels is indicted by the large standard deviation in each cell of Table 4 .

In Table 4, when we examine students who began the year at strategic levels, it is somewhat easier to see clear signs for potential system improvements. Indications of accelerated learning in Tier 2 can be seen in the students who began the year at strategic levels and ended the year reaching the end-of-year goals. About $40 \%$ of the students are in this category. Around $36 \%$ of the students remained at moderate risk at the end of the year, and about $24 \%$ of the students ended the year at high risk (i.e., their level of risk became greater over the year). Without a clear comparison standard, we can only speculate as to whether these percentages represent a strong integration of Tiers 1 and 2, a weak integration, or something in between. Clearly, however, these students exhibited more variability in outcomes compared to students who received only Tier 1 instruction, and the distribution of outcomes can serve as a starting point in determining whether instructional support for students who begin grade 1 at moderate risk for reading difficulties improves over time (e.g., from one year to the next).

Again, an important point is that these data vary dramatically among schools. For strategic students in the top quartile schools, on average, $65 \%$ reached the end-of-year reading goals. For strategic students in bottom quartile schools, on average, $18 \%$ reached the end-of-year reading goals. Compared to the variability in how well schools supported benchmark students with Tier 1 supports, the degree to which schools provided effective Tier 1 and 2 supports for strategic students is even more pronounced. In fact, in schools with effective Tier 1 and Tier 2 supports in place, a greater percentage of strategic students reached end-of-year reading goals than benchmark students in schools with ineffective Tier 1 support plans.

\section{Within year response data}

Although it is important to examine yearly response data (fall to spring) as presented in Table 4, perhaps the most 
critical data source for schools to use in an RTI prevention and intervention framework is within year indicators of progress, because teachers and school staff can better use the data to make important instructional adjustments within and across tiers. The use of formative benchmarking data can be useful in these types of analyses. For example, a systematic examination of how many students in Tiers 1, 2, and 3 make adequate progress between the fall and winter benchmarking periods (i.e., beginning of the year to the middle of the year) is presented in Table 5. The data show how benchmark, strategic, and intensive students in the fall performed on nonsense word fluency (a measure of alphabetic understanding) in the winter benchmarking. The data also demonstrate how students progress over time in acquiring the alphabetic principle (Fien et al., 2008; Good, Baker, \& Peyton, 2009). For example, students who began the year with a benchmark instructional recommendation can be tracked to determine whether, as a group, they are progressing towards the winter benchmark goal.

One way for the school to frame the evaluative question is: How effective was our Tier 1 instructional plan in supporting benchmark students in reaching the winter benchmark goal? (Good et al., 2001) Table 5 shows that about $85 \%$ of students who began the year at benchmark reached the winter benchmark goal. Similar to Table 4, these are data across all 33 schools. For benchmark students in the top quartile schools, on average, $95 \%$ reached the end-of-year reading goals. For benchmark students in bottom quartile schools, on average, $71 \%$ reached the end-of-year reading goals.

A second evaluative question is, how effective was our Tier 1 and Tier 2 instructional plans in supporting strategic students in reaching the winter benchmark goal? Table 2 indicates that $48 \%$ of the students who began the year with strategic support needs reached the winter benchmark goal. In top quartile schools, on average, $71 \%$ reached the end-ofyear reading goals. In bottom quartile schools, $25 \%$ reached the end-of-year reading goals. Again, schools differed widely in how effective their Tier 1 and Tier 2 support plans were for strategic students. This framework for identifying the range of variability in tier effectiveness across schools is a critical concept in coupling implementation data with student reading data to identify effective and ineffective tiers of instructional support and instructional practices within those tiers.

\section{Focus on Important Subgroups}

This framework for examining the general effectiveness across tiers of support can be similarly applied to important subgroups of students. For example, DIBELS and SAT-10 data were collected on ELs and English speakers in all 33 schools, allowing school and district staff to examine impact with different groups of students. Disaggregated data can also be used to analyze relative changes in effectiveness across years. Data collected as part of RF were used to examine the performance of two groups of ELs (Baker, Baker, Katz, \& Otterstedt, 2009). The first group of ELs attended 33 schools during the 1st year of program implementation, the 2003-2004 school year. The second group of ELs attended these same schools during the 2005-2006 school year (i.e., the 3 rd year of implementation). Thus, the primary difference between these two groups of ELs is the number of years their schools had participated in RF and provided tiered reading instruction.

Figure 1 displays the percent of EL students reaching formative reading goals (i.e., DIBELS benchmark goals) in each grade $\mathrm{K}-3$ in Year 1 of RF implementation compared to Year 3 of RF implementation. The graph shows that in each grade a higher percentage of ELs reached formative reading goals as schools gained more experience with implementation. Figure 2 displays the same type of information, with the outcome measure being student performance on the high stakes measure (i.e., SAT-10 for K-2 and the Oregon Assessment of Knowledge and Skills in grade

\section{TABLE 5}

\section{Percentage of Students Reading at Different Levels on Nonsense Word Fluency at the Winter Benchmark Based on Beginning of Year Performance (Cohort A First Grade Students in 2008)}

Reading Performance on NWF at the Winter Benchmark

DIBELS Instructional Recommendation at the Beginning of the Year

\begin{tabular}{lcc} 
& \multicolumn{2}{c}{ Deficit } \\
\hline Intensive & $37.10 \%$ & $(19.42)$ \\
Strategic & $9.95 \%$ & $(11.38)$ \\
Benchmark & $1.15 \%$ & $(2.06)$
\end{tabular}

NWF $=$ Nonsense Word Fluency

Note. Each cell represents the mean and standard deviation of 33 school percentages 


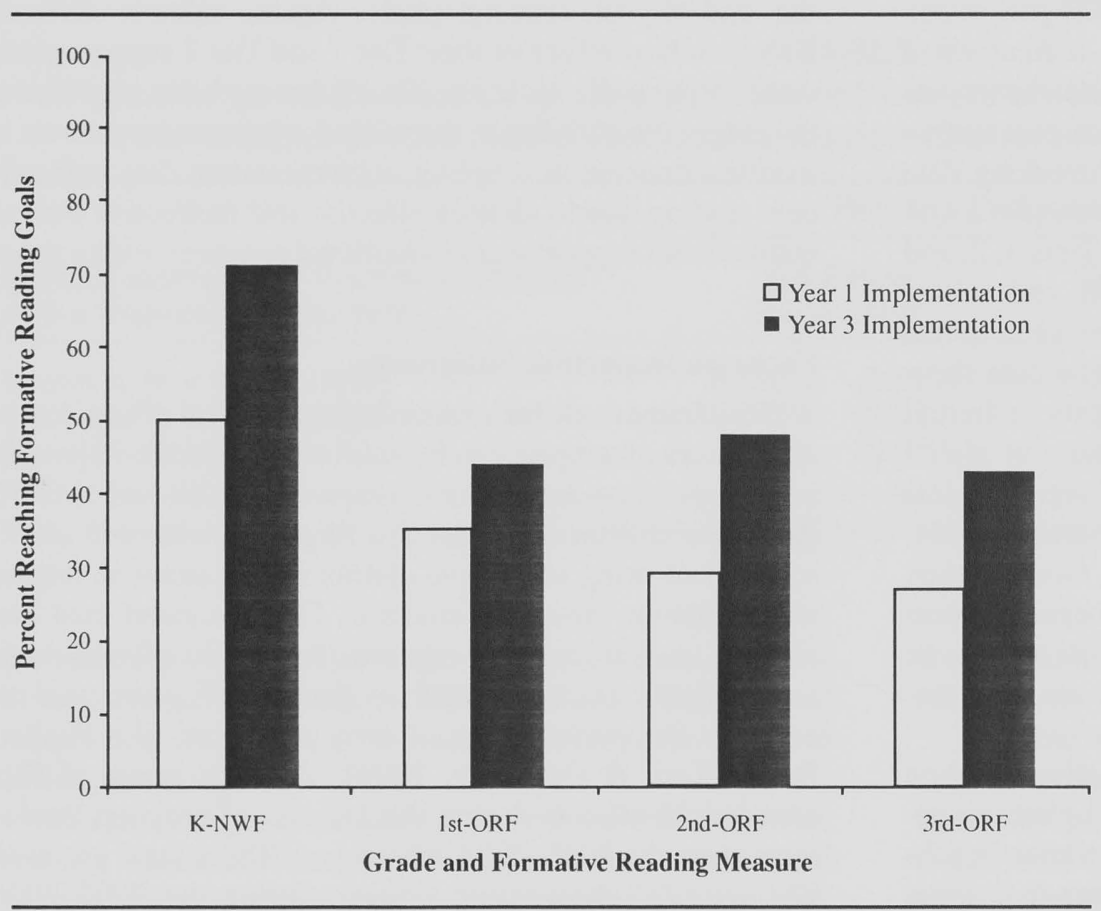

Note. $\mathrm{K}=$ Kindergarten; $\mathrm{NWF}=$ Nonsense Word Fluency; ORF = Oral Reading Fluency

evaluation data, however, is that education leaders have access to disaggregated formative data that can be used in highly purposeful ways to make modifications to tiers of support for students and to evaluate the long term impact of reform initiatives such as RF or RtI for important subgroups.

\section{Implementation Data}

The data in Tables 4 and 5 and Figures 1 and 2 can provide an important basis for evaluating the effectiveness of instructional tiers of support for students overall and for important subgroups of students, including students at different risk levels, students from high poverty backgrounds, and ELs. These evaluations should lead to data-based modifications to improve the quality of instruction within each tier. We suggest an optimal and feasible way to improve instruction within each tier is to base changes on (a) a clear plan for what instructional supports are supposed to be provided and (b) data on what instructional supports are actually provided in each tier and the quality of that support.

\section{Operationalize the plan for tiered instructional support}

The instructional support plan should include details regarding the content of

3). Similar differences by year of implementation were obtained when the contrast variable was the percentage of students who were at high risk for reading difficulties at the end of the year despite having received 1 year of reading instruction.

With ELs, a reasonable conclusion is that this multitiered approach to reading instruction is associated with increased formative reading skills and general reading proficiency and a decrease in reading significantly below grade level. This is significant and meaningful, given the difficulty with largescale initiatives to increase reading achievement for ELs and to close the achievement gap with their English speaking peers.

An essential consideration, however, is that, although improvements appear to accrue for ELs over time, substantial room for improvement remains. Although the percent of students reading significantly below grade level in third grade was reduced considerably from the 1 st to 3 rd year of implementation, $60 \%$ of ELs were still not reaching grade level reading proficiency in schools in the 3 rd year of implementation. Schools and districts need to do a better job with subgroups such as ELs. The main point with these reading instruction (i.e., the what), who will provide instruction (i.e., roles of teachers and instructional assistants), and when and where instruction will occur. This information should be described for each grade and for each tier of support within each grade. The plan should focus on the important big ideas of early reading established by the National Reading Panel (NRP, 2000). Selected interventions, to the extent possible, should be described in the plan as well as the basic procedure the school will use to select evidencebased programs and interventions. A wealth of information regarding current evidence-based programs and interventions is available from various sources online (e.g., What Works Clearinghouse, Florida Center for Reading Research).

\section{Fidelity of implementation}

The concept of fidelity of implementation is fairly straightforward in the context of tiered instruction. An independent observer (e.g., a District Teacher on Special Assignment [TOSA]) should regularly document that the structural elements of the instructional support plan are actually in place. Structural elements include the amount of time scheduled for reading instruction, grouping structures employed, 
and district leaders could use such data sets to develop goals for teachers with either consistently low student achievement or who are normatively discrepant from their peers in terms of effective teaching practices.

\section{SUMMARY}

Our experience with a three-tiered system of instruction in early reading has lead to the following conclusions. An effective Tier 1 system serves two essential purposes. First, when provided to students who are at low risk for reading difficulties (i.e., on track for successful reading outcomes) at the beginning of the year, it enables the vast majority of students to meet challenging formative and summative reading goals by the end of the year. Second, when Tier 1 instruction is provided to students who are at moderate risk for reading difficulties at the beginning of the year, it provides one of two essential instructional support tiers. Together with effective Tier 2 instructional supports, the integration of Tiers 1 and 2 for students at moderate risk for reading difficulties enables these students to reach formative and summative reading goals by the end of the year. In first grade, we argue that the goal for students who begin the year at moderate risk for reading difficulties should be grade-level reading proficiency by the end of the year. That is, students at moderate risk of reading difficulties at the beginning of the year should meet the same challenging formative and summative reading goals at the end of the year as students who begin the year at low risk for reading difficulties.

Student reading data, in particular student response data that documents student progress over a specified time period, should be the primary basis for evaluating the effectiveness of tiers of instructional support. In other words, students reaching important formative and summative reading goals constitute positive evidence for an effective system of instruction. When students do not reach key goals, the evidence suggests the system should be improved in some manner.

However, examining only student reading data is not sufficient for a comprehensive evaluation of the effectiveness of an early reading system. It is also necessary to carefully examine how instruction and tiers of instruction are delivered in the classroom. Toward that end, we suggest three components, along with student reading data, that constitute a comprehensive framework for evaluating implementation: (a) some type of instructional support plan to codify the multitiered system of instructional supports that will be provided across and within each tier, (b) a system documenting whether the plan is being implemented with fidelity in the classroom, and (c) a system for evaluating quality of instruction-the extent to which instruction is systematic and explicit-particularly in early reading.

\section{REFERENCES}

Adams, M. J. (1990). Beginning to read: Thinking and learning about print. Cambridge, MA: MIT Press.

Archer, A. (2006, January 23). Dynamic vocabulary instruction in the elementary school. Paper presented at the Oregon Reading First, Eugene, OR.

Baker, D. L., Baker, S. K., Katz, R., \& Otterstedt, J. (2009). The English reading performance of English learners in Oregon Reading First across three years of implementation. Retrieved from http:// oregonreadingfirst.uoregon.edu/

Baker, S. K., Gersten, R., Haager, D., \& Dingle, M. (2006). Teaching practice and the reading growth of first-grade English learners: Validation of an observation instrument. The Elementary School Journal, 107(2), 199-220. doi: 10.1086/510655

Baker, S. K., Gersten, R., \& Scanlon, D. (2002). Procedural facilitators and cognitive strategies: Tools for unraveling the mysteries of comprehension and the writing process, and for providing meaningful access to the general curriculum. Learning Disabilities Research and Practice, 17(1), 65-77.

Baker, S. K., Simmons, D. C., \& Kame'enui, E. J. (1995). Vocabulary acquisition synthesis of the research. Eugene, OR; Washington, DC: National Center to Improve the Tools of Educators College of Education University of Oregon; U.S. Dept. of Education Office of Educational Research and Improvement Educational Resources Information Center.

Baker, S. K., Simmons, D. C., \& Kame'enui, E. J. (1998). Vocabulary acquisition: Research bases. In D. Simmons \& E. Kame'enui (Eds.), What reading research tells us about children with diverse learning needs (pp. 183-218). Mahwah, NJ: Erlbaum.

Baker, S. K., Smith, J. M., Fien, H., Otterstedt, J., Katz, R., Baker, D. L., et al. (2007). Three year Oregon Reading First report. Retrieved from http://oregonreadingfirst.uoregon.edu/

Baker, S. K., Smolkowski, K., Katz, R., Fien, H., Seeley, J., Kame'enui, E., et al. (2008). Reading fluency as a predictor of reading proficiency in low-performing high poverty schools. School Psychology Review, 37, 18-37.

Baker, S. K., Smolkowski, K., Smith, J. M., Fien, H., Kame'enui, E., \& Thomas Beck, C. (in press). The impact of Oregon Reading First on student reading outcomes. Elementary School Journal.

Baumann, J. F., \& Kame'enui, E. (1991). Research on vocabulary instruction: Ode to Voltaire. In J. Flood, D. Lapp \& J. Squires (Eds.), Handbook of research on teaching the English language arts (pp. 604-632). Upper Saddle River, NJ: Merrill/Prentice Hall.

Baumann, J. F., Kame'enui, E. J., \& Ash, G. E. (2003). Research on vocabulary instruction: Voltaire redux. In J. Flood, D. Lapp, J. R. Squire \& J. M. Jensen (Eds.), Handbook of research on teaching the English language arts (pp. 752-785). Mahwah, NJ: Elrlbaum.

Beck, I. L., \& McKeown, M. G. (2006). Improving comprehension with questioning the author: A fresh and expanded view of a powerful approach. New York: Scholastic.

Beck, I. L., McKeown, M. G., \& Kucan, L. (2002). Bringing words to life: Robust vocabulary instruction. Solving problems in the teaching of literacy. New York: Guilford.

Beck, I. L., McKeown, M. G., \& Kucan, L. (2008). Creating robust vocabulary: Frequently asked questions and extended examples. New York: Guilford.

Biancarosa, G., \& Snow, C. E. (2006). Reading next: A vision for action and research in middle and high school literacy (2nd ed.). Washington, DC: Alliance for Excellent Education.

Biemiller, A. (2001). Teaching vocabulary: Early, direct, and sequential. American Educator, 25(1), 24-28, 47. 
Bogdan, R. C., \& Biklen, S. K. (2006). Qualitative research for education: An introduction to theories and methods. Boston: Pearson Education.

Borman, G. D., Hewes, G. M., Overman, L. T., \& Brown, S. (2003). Comprehensive school reform and student achievement: A metaanalysis. Review of Educational Research, 73(2), 125-230.

Burns, M. K., \& Vanderheyden, A. (2006). Response to Intervention to assess learning disabilities: Introduction to the special series. Assessment for Effective Instruction, 32, 3-5.

Carnine, D. (1992). Introduction. In D. Carnine \& E. Kame'enui (Eds.), Higher order thinking: Designing curriculum for mainstreamed students (pp. 1-22). Austin, TX: Pro-Ed.

Carnine, D., \& Kame'enui, E. (1992). Higher order thinking: Designing curriculum for mainstreamed students Austin, TX: Pro-Ed.

Carnine, D., Silbert, J., Kame'enui, E., \& Tarver, S. (2004). Direct instruction reading (4th ed.). Upper Saddle River, NJ: Pearson.

Chard, D., Harn, B., Sugai, G., Horner, R., Simmons, D., \& Kame'enui, E. (2008). Core features of multi-tiered systems of reading and behavioral support. In C. R. Greenwood, T. R. Kratochwill, \& M. Clements (Eds.), Schoolwide prevention models: Lessons learned in elementary schools (pp. 31-61). New York: Guildford.

Chard, D. J., \& Jungjohann, K. (2006). Scaffolding instruction for success in mathematics learning, intersection: Mathematics education sharing common grounds. Houston, TX: Exxon-Mobil Foundation.

Clements, M., \& Kratochwill, T. R. (2009). Multi-tiered prevention models: Implications and future perspectives. In C. R. Greenwood, T. R. Kratochwill, \& M. Clements (Eds.), Schoolwide prevention models: Lessons learned in elementary schools (pp. 269-291). New York: Guildford.

Cohen, L., Manion, L., \& Morrisson, K. R. B. (2000). Research methods in education. London: Routledge.

Coyne, M., Kame'enui, E., \& Carnine, D. (2006). Effective teaching strategies that accommodate diverse learners (3rd ed.). Upper Saddle River, NJ: Pearson.

Desimone, L. (2002). How can comprehensive school reform models be successfully implemented? Review of Educational Research, 72(3), 433-479. doi: 10.3102/00346543072003433

Farr, R., Tulley, M. A., \& Powell, D. (1987). The evaluation and selection of basal readers. The Elementary School Journal, 87(3), 266. doi: $10.1086 / 461494$

Fien, H., Baker, S. K., Smolkowski, K., Smith, J. M., Kame'enui, E. J., \& Thomas Beck, C. (2008). Using nonsense word fluency to predict reading proficiency in $\mathrm{K}-2$ for English learners and native English speakers. School Psychology Review, 37(3), 391-408.

Francis, D. J., Fletcher, J. M., Stuebing, K. K., Davidson, K. C., \& Thompson, N. M. (1991). Analysis of change: Modeling individual growth. Journal of Consulting and Clinical Psychology, 59(1), 27-37.

Fuchs, D., Fuchs, L. S., \& Burish, P. (2000). Peer-assisted learning strategies: An evidence-based practice to promote reading achievement. Learning Disabilities Research \& Practice, 15(2), 85-91.

Fuchs, D., Fuchs, L. S., McMaster, K. L., \& Al Otaiba, S. (2005). Identifying children at risk for reading failure: Curriculum-based measurement and the dual. In H. L. Swanson, K. R. Harris \& S. Graham (Eds.), Handbook of Learning Disabilities (pp. 431-450). New York: Guilford Press.

Fuchs, D., Mock, D., Morgan, P. L., \& Young, C. L. (2003). Responsiveness-to-intervention: Definitions, evidence, and implications for the learning disabilities construct. Learning Disabilities Research and Practice, 18(3), 157-171.
Fuchs, L. S., Fuchs, D., \& Zumeta, R. O. (2008). A curricular-sampling approach to progress monitoring: Mathematics concepts and applications. Assessment for Effective Intervention, 33(4), 225-233. doi: 10.1177/1534508407313484

Gersten, R., Baker, S., \& Lloyd, J. W. (2000). Designing high-quality research in special education: Group experimental design. Journal of Special Education, 34(1), 2-18.

Gersten, R., Baker, S. K., \& Marks, S. U. (1998). Teaching Englishlanguage learners with learning difficulties: Guiding principles and examples from research-based practice. Reston, VA: ERIC Clearinghouse on Disabilities and Gifted Education.

Gersten, R., Baker, S. K., Pugach, M. C., Scanlon, D., \& Chard, D. (2001). Contemporary research on special education teaching. In V. Richardson (Ed.), Handbook for Research on Teaching (4th ed., pp. 695-722). Washington, DC: American Educational Research Association.

Gersten, R., Baker, S. K., Shanahan, T., Linan-Thompson, S., Collins, P., \& Scarcella, R. (2007). Effective literacy and English language instruction for English learners in the elementary grades: A Practice Guide. Washington, DC: National Center for Education Evaluation and Regional Assistance, Institute of Educational Sciences, U.S. Department of Education.

Gersten, R., \& Carnine, D. (1986). Direct instruction in reading comprehension. Educational Leadership, 43(7), 70-78.

Gersten, R., Carnine, D., \& Woodward, J. (1987). Direct instruction research: The third decade. Remedial and Special Education (RASE), 8(6), 48-56.

Gersten, R., Carnine, D. W., \& White, W. A. (1984). The pursuit of clarity: Direct instruction and applied behavior analysis. In W. Heward, T. E. Heron, D. S. Hill, \& J. Trap-Porter (Eds.), Focus on behavior analysis in education (pp. 38-57). Columbus, $\mathrm{OH}$ : Merrill.

Gersten, R., Chard, D., \& Baker, S. (2000). Factors that enhance sustained use of research-based instructional practices: A historical perspective on relevant research. Journal of Learning Disabilities, 33, 444- 457 .

Gersten, R., Chard, D. J., Jayanthi, M., Baker, S. K., Morphy, P., \& Flojo, J. (2009). Mathematics instruction for students with learning disabilities: A meta-analysis of instructional components. Review of Educational Research, 79(3), 1202-1242.

Gersten, R., Compton, D., Santoro, L. E., Dimino, J., Linan-Thompson, S., \& Tilly, D. (2008). Response to Intervention (RTI) \& multitier intervention for reading in the primary grades. Washington, DC: U.S. Department of Education, Institute for Education Sciences.

Goldenberg, C., \& Patthey-Chavez, G. (1995). Discourse processes in instructional conversations: Interactions between teacher and transition readers. Discourse Processes, 19(1), 57-74.

Good, R., Baker, S., \& Peyton, J. (2009). Making sense of nonsense word fluency: Determining adequate progress in early first grade reading. Reading \& Writing Quarterly, 25, 33-56.

Good, R. H., Gruba, J., \& Kaminski, R. (2001). Best practices in using Dynamic Indicators of Basic Early Literacy Skills (DIBELS) in an outcomes-driven model. In A. Thomas \& J. Grimes (Eds.), Best practices in school psychology (Vol. IV, pp. 679-700). Washington, DC.: National Association of School Psychologists.

Graves, M. F. (2006). The vocabulary book: Learning and instruction. New York, NY: Teachers College Press, International Reading Association, and National Council of Teachers of English.

Greenwood, C. R., Delquadri, J. C., \& Hall, R. V. (1984). Opportunity to respond and student academic performance. In W. L. Heward, T. E. Heron, D. S. Hill, \& J. Trap-Porter (Eds.), Focus on behavior analysis in education (pp. 58-88). Columbus, $\mathrm{OH}$ : Merrill. 
Greenwood, C. R., Horner, R. H., \& Kratochwill, T. R. (2008). Introduction. In C. R. Greenwood, T. R. Kratochwill \& M. Clements (Eds.), Schoolwide prevention models: Lessons learned in elementary schools (pp. 3-31). New York: Guildford Press.

Greenwood, C. R., Kratochwill, T. R., \& Clements, M. (2008). Schoolwide prevention models: Lessons learned in elementary schools. New York: Guilford Press.

Gunn, B., Smolkowski, K., Biglan, A., Black, C., \& Blair, J. (2005). Fostering the development of reading skill through supplemental instruction: Results for Hispanic and non-Hispanic students. Journal of Special Education, 39(2), 66-85.

Haager, D., Klinger, J. K., \& Vaughn, S. (2007). Validated reading practices for three tiers of intervention. Baltimore: Brookes.

Haynes, N. M. (1998). Changing schools for changing times: The Comer School Development Program. Mahwah, NJ: Erlbaum.

Hoffman, J. V., McCartney, S. J., Abbott, J., Christian, C., Corman, L., Curry, C., et al. (1994). So what's new in the new basals? A focus on first grade. Journal of Literacy Research, 26(1), 47-73.

Jenkins, J. R., Stein, M., \& Wysocki, K. (1984). Learning vocabulary through reading. American Educational Research Journal, 21, 767-787.

Kame'enui, E. J., Simmons, D. C., \& Coyne, M. D. (2000). Schools as host environments: Toward a school-wide reading improvement model. Annals of Dyslexia, 50, 31-52.

Kamil, M. L., Borman, G., Dole, J., Kral, C. C., Salinger, T., \& Torgesen, J. K. (2008). Improving adolescent literacy: Effective classroom and intervention practices: A practice guide. Washington, DC: National Center for Education Evaluation and Regional Assistance, Institute of Education Sciences, U.S. Department of Education.

Marsh, D. (1994). Change in schools: Lessons from the literature. In P. Wohlstetter \& S. A. Mohrman (Eds.), School-based management: Promise and process (pp. 215-252). San Francisco: Jossey-Bass.

Mathes, P. G., Denton, C. A., Fletcher, J. M., Anthony, J. L., Francis, D. J., \& Schatschneider, C. (2005). The effects of theoretically different instruction and student characteristics on the skills of struggling readers. Reading Research Quarterly, 40(2), 148-182.

National Association of State Directors of Special Education. (2006). Response to Intervention: Policy considerations and implementation. Alexandria, VA: Author.

National Reading Panel. (NRP). (2000). Teaching children to read: An evidence-based assessment of the scientific research literature on reading and its implications for reading instruction. Washington, DC: National Institute of Child Health and Human Development.

National Research Council. (NRC). (1998). Preventing reading difficulties in young children. Washington, DC: National Academny Press.

Newmann, F. M., Marks, H. M., \& Gamorran, A. (1996). Authentic achievement: Restructuring schools for intellectual quality. San Francisco: Jossey-Bass.

O'Conner, R. (2007). Layers of intervention that affect outcomes in reading. In D. Haager, J. Klingner, \& S. Vaughn (Eds.), Evidencebased reading practices for Response to Intervention. Baltimore: Brookes.

Patching, W., Kameenui, E. J., Carnine, D., Gersten, R., \& Colvin, G. (1983). Direct instruction in critical reading skills. Reading Research Quarterly, 18(4), 406-418.

Pianta, R. C., \& Hamre, B. K. (2009). Conceptualization, measurement, and improvement of classroom processes: Standarized observation can leverage capacity. Educational Researcher, 38, 109-119.

Porter, A. C., \& Smithson, J. L. (2001). Are content standards being implemented in the classroom? A methodology and some tentative answers. In S. H. Furhman (Ed.), From the capitol to the classroom: Standards-based reform in the states (Vol. Part II, pp. 60-80). Chicago: National Society for the Study of Education distributed by Univeristy of Chicago Press.

Raudenbush, S. W. (2008). Advancing educational policy by advancing research on instruction. American Educational Research Journal, 45(1), pp. 206-230.

Raudenbush, S. W. (2009). The Brown legacy and the O'Connor challenge: Transfoming schools in the images of children's potential. Educational Researcher, 38, 169-180.

Reynolds, C. R., \& Shaywitz, S. E. (2009). Response to Intervention: Prevention and remediation, perhaps. Diagnosis, no. Child Development Perspectives, 3(1), 4447.

Simmons, D., \& Kame'enui, E. (2000). A consumer's guide to evaluating a core reading program grades $K-3:$ A critical elements analysis. Eugene: University of Oregon, National Center to Improve the Tools of Educators.

Simmons, D., Kame'enui, E., Good, R. H., III, Harn, B., Cole, C., \& Braun, D. (2002). Building, implementing, and sustaining a beginning reading improvement model: Lessons learned school by school. In M. R. Shinn, H. M. Walker, \& G. Stoner (Eds.), Interventions for academic and behavior problems II: Preventive and remedial approaches (pp. 537-570). Washington, DC: National Association of School Psychologists.

Snow, C. E., Burns, M. S., \& Griffin, P. (1998). Preventing reading difficulties in young children. Washington, DC: National Academy Press.

Stringfield, S., Millsap, M. A., Yoder, N., Brigham, N., Nesselrodt, P., Schaffer, E., et al. (1997). Urban and suburban/rural strategies for educating disadvantaged children: Third year report. Washington, DC: U.S. Department of Education, Planning and Evaluation Service.

Torgesen, J. K. (1997). The prevention and remediation of reading disabilities: Evaluation what we know from research. Journal of Academic Language Therapy, 1, 11-47.

Torgesen, J. K. (2004). Preventing early reading failure and its devastating dowward spiral. American Educator, 28, 3-21.

Torgesen, J. K., Wagner, R. K., Rashotte, C. A., Rose, E., Lindamood, P., Conway, T., et al. (1999). Preventing reading failure in young children with phonological processing disabilities: Group and individual responses to instruction. Journal of Educational Psychology, 91(4), 579-593.

Vadasy, P. F., Sanders, E. A., \& Peyton, J. A. (2005). Relative effectiveness of reading practice or word-level instruction in supplemental tutoring: How text matters. Journal of Learning Disabilities, 38(4), 364.

Vaughn, S., \& Fuchs, L. S. (2006). A response to "Competing views: A dialogue on Response to Intervention": Why response to intervention is necessary but not sufficient for identifying students with learning disabilities. Assessment for Effective Intervention, 32(1), 58.

Vaughn, S., Wanzek, J., Woodruff, A. L., \& Linan-Thompson, S. (2007). Prevention and early identification of students with reading disabilities. In D. Haager, J. K. Klinger \& S. Vaughn (Eds.), Evidence-based reading practices for reponse to intervention (pp. 11-27). Baltimore: Brookes.

Walker, H. M., \& Shinn, M. (2002). Structuring school-based interventions to achieve integrated primary, secondary, and tertiary prevention goals for safe and effective schools. In M. R. Hill, H. M. Walker, \& G. Stoner (Eds.), Interventions for academic and behavior problems II: Preventive and remedial approaches (pp. 1-25). Bethesda, MD: National Association of School Psychologists. 